\title{
Assessing Nurses' Knowledge and Auditing their Practices Regarding Nursing Care Documentation
}

\author{
Nora Ahmed Hassan, Assist .Prof. Dr. Mona Mostafa shazly , Dr. Rasha Ibrahim \\ El-Sayed Aly \\ B.Sc, Mansoura University, Assist Assistant Professor of Nursing Administration, \\ Faculty of Nursing-Ain-Shams University,Lecturer of Nursing Administration, \\ Faculty of Nursing - Port Said University.
}

\begin{abstract}
Background: Nursing documentation is essential for quality of care, which facilitates continuity and individuality of care. Aim of the study: The study was aimed at assessing nurses' knowledge and auditing their practices regarding nursing care documentation. Setting: It was carried out in the medical and surgical units of Mansoura University Hospital. Design: using an analytic cross-sectional design. Subjects: Consisted o f 100 staff nurses and 557 nursing care charts. Tools and procedure: were a self-administered questionnaire and an audit sheet. The fieldwork lasted from April to July 2015. Results: The study revealed that nurses' age ranged between 20 and 60 years, $77.0 \%$ having nursing diploma. 38\% of the nurses had satisfactory knowledge about documentation. $18 \%$ of the nurses agreed upon the barriers hindering the quality of nursing documentation. Conclusion: the nurses in the study setting have inadequate knowledge about documentation, and minorities of them agree about the barriers hindering quality of documentation. Nurses' audited practice is low. Recommendations: staff development activities are urgently recommended to improve nurses' knowledge and practice.
\end{abstract}

Key word: Audit, Barriers, Knowledge, Nursing documentation 


\section{INTRODUCTION}

The quality of nursing documentation enables transparent and consistent approaches to the planning and delivery of care; it is the cornerstone for professional practice (Leach, 2008). Nursing documentation is written or electronically generated information that describes the care or service provided to a particular client or group of clients. Through documentation, nurses communicate to other healthcare professionals their observations, decisions, actions and outcomes of care. Documentation is an accurate account of what occurred and when it occurred (College of Registered Nurses of British Columbia, 2013).

Nursing documentation is based on the nursing process so the client's needs can be traced from assessment, through identification of the problem solving to the care plan, implementation and evaluation (Ladner and Delaune, 2011). By knowing how to document, what to document, when to document, and even who should document, the nurse will create a solid record (Kluwer, 2007).

Every nurse/healthcare professional must be familiar with their organizational policies or procedures related to documentation to operate within what is acceptable and avoid getting into problems (Chelagat et al., 2013). The general principles of nursing documentation are objectivity, specificity, clearly and consistently, recording all relevant information including communications with other members of the health team, respecting confidentiality, and recording errors (American Nurses Association

\section{House of Delegates, 2005).}

Records and reports are indispensable aids to all who are responsible for giving the best possible service to the individuals, families and to the community. Record is a written communication that permanently documents information relevant to client's healthcare management. It is continuing account of the client's healthcare needs, where report is oral or written information about a patient by one member of health team to another (Lucita, 2007).

Systems of recording and reporting client care data have evolved primarily in response to demands that healthcare practitioners be held to societal norms, professional standards of practice, legal and regulatory standards, and institutional policies and standards. The systems used today reflect specific needs and preferences of various healthcare agencies. They include i) narrative charting; ii) source-oriented 
charting; iii) problem-oriented charting; iv) pie (problem, intervention, and evaluation) charting; v) focus charting; vi) charting by exception; vii) computerized documentation; and viii) critical pathways (DeLaune and Ladner, 2011).

The forms for recording data include Kardex, nurse's progress notes, flow sheets, discharge summaries (White, 2005), and nursing care plan (Hoban, 2003). They are designed to facilitate record keeping and allow quick, easy access to information (White et al., 2011).

Unfortunately, in spite of the importance of nursing documentation, research reports from many countries showed that the nurses' performance regarding documentation of cares were weak (Darmer et al., 2004). Cheevakasemsook et al. (2006) reported that $41 \%$ of nursing documents have a low quality and in $50 \%$ of documents legal aspects did not considered, disruption of documentation activities, limited nurses' competence in documenting, and inadequate supervision. Moreover, documentation is reported to take up to $50 \%$ of nurses' time per shift (Gugerty et al., 2007).

Having unique body of knowledge and skills is traditionally seen as the hallmark of professional practice (Moulster and Turnbull 2004). Nurses have up-to-date knowledge and skills, and use these with intelligence, insight and understanding in line with the needs of each individual in their care (Gordon and Watts, 2011). Knowledge is basically what classifies nurses as professionals having a unique body of knowledge as one of the things that define a profession in a society (Hall, 2005; Jones, 2012). With knowledge of the concepts and of the process, nurses have a scientific base for practice that can be clearly articulated to show quality of care (Parker and Smith, 2010).

Nursing audit is a method of evaluating nursing practice by reviewing records that document the care provided to patients (Medical Dictionary for the Health Professions and Nursing Farlex, 2012). There are three methods of audit: retrospective nursing audit, concurrent nursing audit, and prospective nursing audit. Retrospective nursing audit is a method of evaluating the quality of nursing care by examining the nursing care as it reflected in patient care records for discharged patient. A concurrent nursing audit refers to evaluations conducted during ongoing nursing care. A prospective nursing audit is attempted to identify how future performance will be affected by current interventions (Phillips, 2010). 


\section{Significance of the study:}

Nursing documentation is limited and inadequate for evaluating the actual care given. Given the significance of nursing documentation and the reality of poor documentation practices, it is crucial to assess the quality of nursing documentation and to identify the factors underlying its deficiency. Chart audit can help to achieve this. Therefore, this study was aimed at assessing nurse's knowledge and auditing their practices regarding nursing care documentation in Mansoura University Hospital.

\section{AIM OF STUDY:}

The aim of the present study is to assess nurses' knowledge and auditing their practices regarding nursing care documentation.

\section{Research questions:}

1. What is the level of nurse's knowledge regarding documentation in Mansoura University Hospital?

2. Are nurses applying nursing documentation criteria effectively in Mansoura University Hospital?

3. Is there a relation between nurses' knowledge, attitude and their practice in Mansoura University Hospital?

\section{Subjects and Method:}

\section{Technical Design:}

-Research design: An analytic cross-sectional design was used in conducting this study.

-Setting: The study was carried out in the medical and surgical units of Mansoura University Hospital.

\section{Sampling design:}

Target Sample: The study sample included two groups named staff nurses and patients' charts. 
Staff nurses: The study sample included all staff nurses working in the medical, surgical, and orthopedic units at Mansoura University Hospital during the time of the study. Their total number was 100 staff nurses. The only inclusion criterion was having at least one-year experience in their current job.

Patients' charts: These included nursing care charts at the selected units for three months retrospectively from May 2015 to July 2015. The study sample consisted of 557 patients' charts from the same general medical and surgical units where the selected staff nurses were working. The only inclusion criterion for selecting charts was that patient had at least 2-day hospital stay.

Sampling technique: A systematic random sampling technique was used to select the patients' charts according to eligibility criteria until the required sample size was fulfilled.

\section{Tools of data Collection:-}

Two different tools were used in the study for data collection.

Tool (1): Self-administered questionnaire (Appendix I): The researcher prepared this questionnaire based on related literature (Said, 2007). It consisted of the following parts:-

○ Part 1 (personal and job characteristics): This part included questions about nurse's personal data and job characteristics such as work unit, age, nursing qualification, and years of experience.

○ Part II (Knowledge questionnaire): It consists of 18 multiple-choice questions (MCQs)

Scoring: For each knowledge item, a correct response was scored 1 and the incorrect zero. For each area of knowledge, the scores of the items were summed-up and the total divided by the number of the items, and converted into percent scores. Knowledge was considered satisfactory if the percent score was $60 \%$ or more and unsatisfactory if less than $60 \%$.

○ Part III (nurse's opinions regarding documentation barriers): This part consisted of 27 statements on a 3-point Likert scale "agree, uncertain, and disagree."

Scoring: Statements' responses "agree", "uncertain", and "disagree” were respectively scored 3, 2, and 1. Scoring was reversed for negative statement. The scores of the 
items of each category and for the total scale were summed-up and the total divided by the number of the items, and converted into percent scores. The nurse was considered to "agree" on barriers if the percent score was $60 \%$ or more and "disagree" if less than $60 \%$.

○ Part IV: This included 17 different suggestions to improve the quality of nursing documentation.

Tool (2): Audit checklist (Appendix II): it developed by Said (2007) and modified by the researcher. It consisted of two parts.

○ Part I: This included patient identification information such as name, age, gender, marital status, admission date, diagnosis, and ward.

O Part II: This part consisted of the auditing checklist for documentation of nursing care in patient chart. The checklist included 78 items to be checked "Done" or "Not done" or "Not applicable."

Scoring: In the audit checklist, the items "not done" and "done" were scored " 0 " and "1", respectively. The items "not applicable" were not scored and were discounted from the totals. For each part, the scores of the items were summed-up and the total divided by the number of the items, and converted into percent scores. The nurse's audit was considered adequate if the percent score was $60 \%$ or more and inadequate if less than $60 \%$.

\section{II- Administrative Design and Ethical Considerations:}

An official letter addressed from the Dean of the Port Said Faculty of Nursing to Mansoura University Hospital medical and nursing directors to obtain their permission for conducting the study. It explained the study objective and its procedures. Moreover, an official letter was addressed to the office of patients' relations to take their permission to retrieve patients' charts for the purpose of auditing.

\section{III-Operational design:}

Preparatory phase: During this phase, the researcher reviewed the literature related to the study subject using paper and electronic sources both locally and internationally. This helped in the selection and preparation of the data collection tools.

Content validity: Upon preparation of the preliminary forms of the tools, they were presented to a panel of 7 experts for face and content validation. They were from 
Nursing Administration and Medical-Surgical nursing departments from Mansoura, Ain Shams and Port Said Faculties of Nursing. They assessed the tool for clarity, relevance, comprehensiveness, understanding and ease for implementation. According to their opinions, minor modifications were applied. The tools were then modified according to their recommendations and suggestions.

Testing reliability: Cronbach alpha coefficient was calculated to assess the reliability of the developed tools through its internal consistency.

Pilot study: A pilot study was carried out on ten staff nurses and 57 patients' charts from the study setting, representing $10 \%$ of the sample size. The purposes of the pilot study were to ascertain the clarity and feasibility of the tools, and to detect any possible problems concerning data collection tools that might face the researcher and interfere with data collection. It also helped to identify the suitable time and place for data collection, and to estimate the exact time needed for data collection.

The field work: After obtaining an official agreement from the hospital director and the heads of the medical and surgical departments, the researcher met with the selected staff nurses, explained to them the aim and process of the study, and invited them to participate. The self-administered questionnaire was distributed to those who gave their consent to participate. Each staff nurse took a period of about 15-20 minutes to fill in the form. The data were collected from nurses along one month from April 1 to May 1. The setting was visited two days per week for four hours each time. Then, the process of nursing audit was started. The researcher selected the charts according to the set criteria. Then, using the audit checklist, each chart was assessed for meeting the standards of quality documentation. Each chart took about 15-20 minutes to be checked. The data were collected during a period of three months from May 1 to July 30. The researcher visited the hospital three days per week for four hours each time to fulfill the auditing process.

VI-Statistical Analysis: Data entry and statistical analysis were done using SPSS 20.0 statistical software package. Data were presented using descriptive statistics in the form of frequencies and percentages for qualitative variables, and means and standard deviations and medians for quantitative variables. 


\section{RESULTS:}

Table (1): shows that the age of the nurses ranged between 20 and 59 years with mean of $33.4 \pm 9.8$. More than three quarters $(77.0 \%)$ were having secondary school nursing diploma. Their experience years ranged between $<1$ to 40 with mean of 15.4 \pm 10.0 . The majority of the staff nurses were currently married $(83.0 \%)$.

Table (2): demonstrates that nurses' knowledge about documentation was generally inadequate. The percentages of those who having satisfactory knowledge ranged between $42 \%$ for documentation principles and $51 \%$ for the importance of documentation.

Figure (1): displays that about more than one-third (38\%) of the nurses in the study sample were having satisfactory knowledge about documentation.

Figure (2): illustrates that only less than one-fifth (18\%) of the nurses in the study sample agreed upon the barriers hindering the quality of nursing documentation.

Figure (3): displays, only one $(0.2 \%)$ of the audited records had adequate nursing documentation.

Figure (4): Investigating the relations among nurses' scores of knowledge and audit towards barriers using the ecologic correlation method, statistically significant strong negative correlations were revealed between the scores of knowledge and audit ( $r=-$ $0.738)$. 
Table (1): Personal and job characteristics of nurses in the study sample $(n=100)$

\begin{tabular}{|l|r|r|}
\hline \multicolumn{1}{|c|}{ Personal and job characteristics of nurses } & Frequency & Percent \\
\hline Age: & 48 & 48.0 \\
$30+$ & 52 & 52.0 \\
Range & $20.0-59.0$ \\
Mean \pm SD & $33.4 \pm 9.8$ \\
\hline Educational qualification: & 77 & \\
Nursing school diploma & 23 & 23.0 \\
Technical Institute diploma & & \\
\hline Current marital status: & 17 & 17.0 \\
Unmarried (single/divorced/widow) & 83 & 83.0 \\
Married & & \\
\hline Experience years: & 71 & 71.0 \\
$<20$ & 29 & 29.0 \\
$20+$ & $1.0-40.0$ & \\
Range & $15.4 \pm 10.0$ \\
Mean \pm SD & & \\
\hline
\end{tabular}

Table (2): Distribution of nurses Knowledge about documentation items in the selected units $(\mathrm{n}=100)$

\begin{tabular}{|l|r|r|}
\hline Satisfactory knowledge (60\%+) of: & Frequency & Percent \\
\hline Documentation system & 50 & 50.0 \\
Documentation principles & 42 & 42.0 \\
Importance of documentation & 51 & 51.0 \\
\hline
\end{tabular}




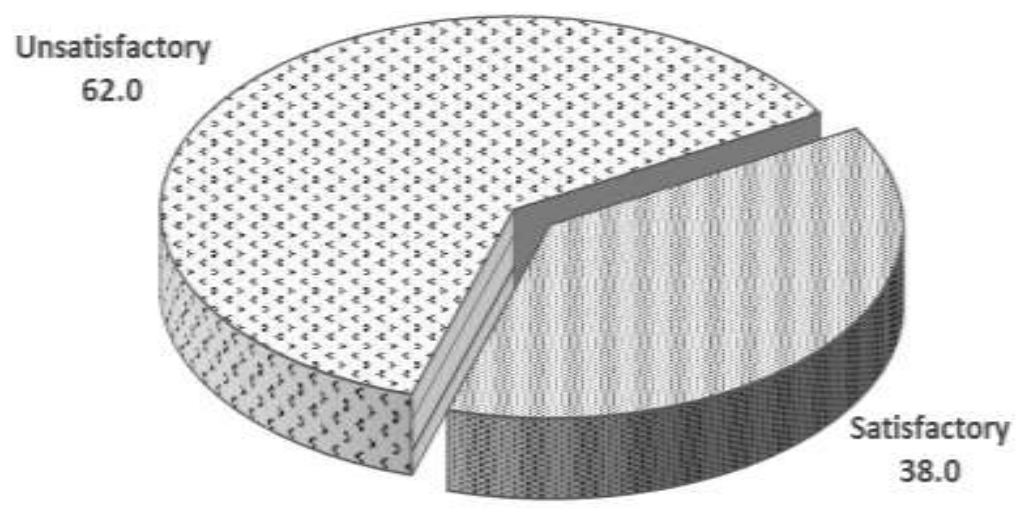

Figure (1) nurses Knowledge about documentation in the selected units ( $n=100)$

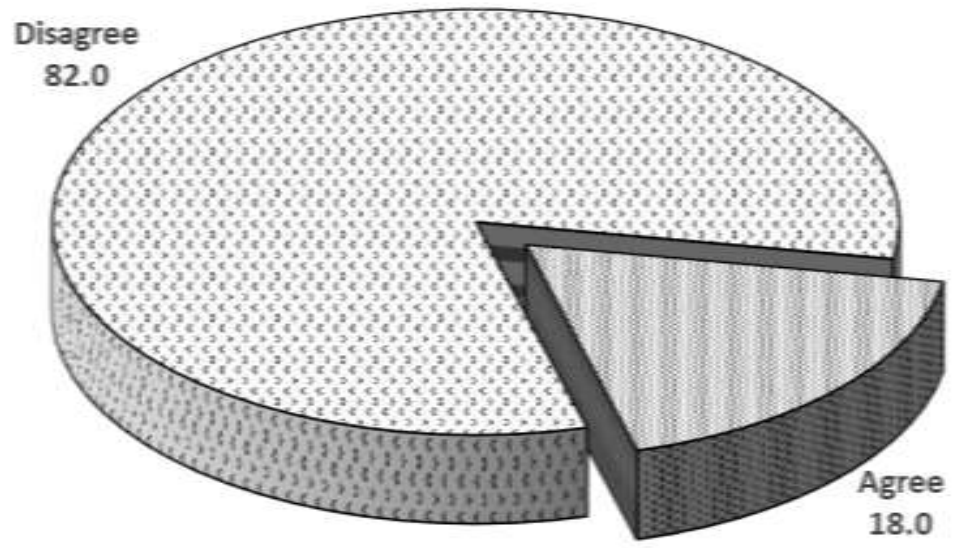

Figure (2) Barriers hindering documentation as agreed upon by nurses in the study sample $(n=100)$

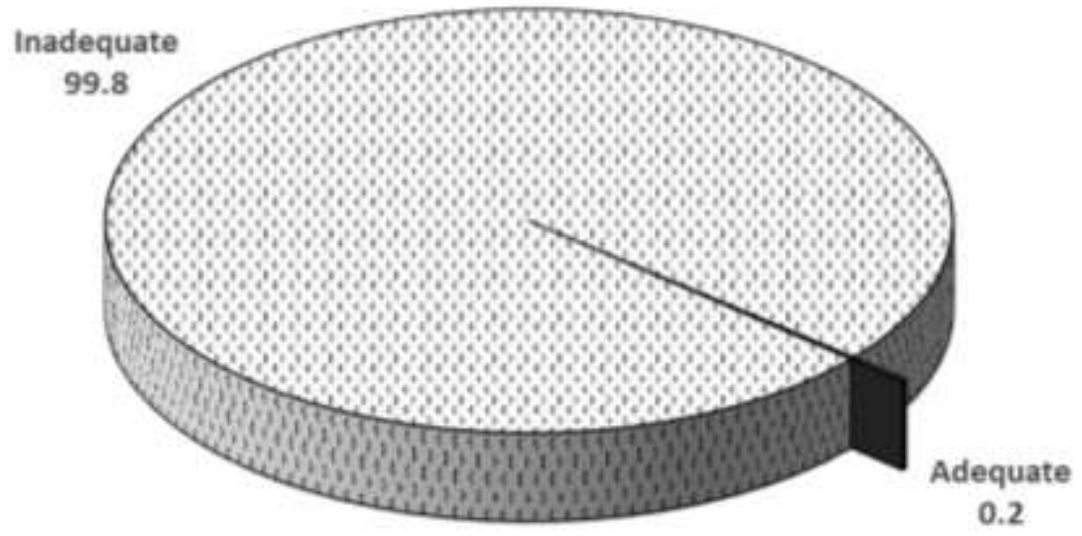

Figure (3): Nurses practice of documentation principles in the patients charts in selected units $(\mathbf{n}=557)$ 


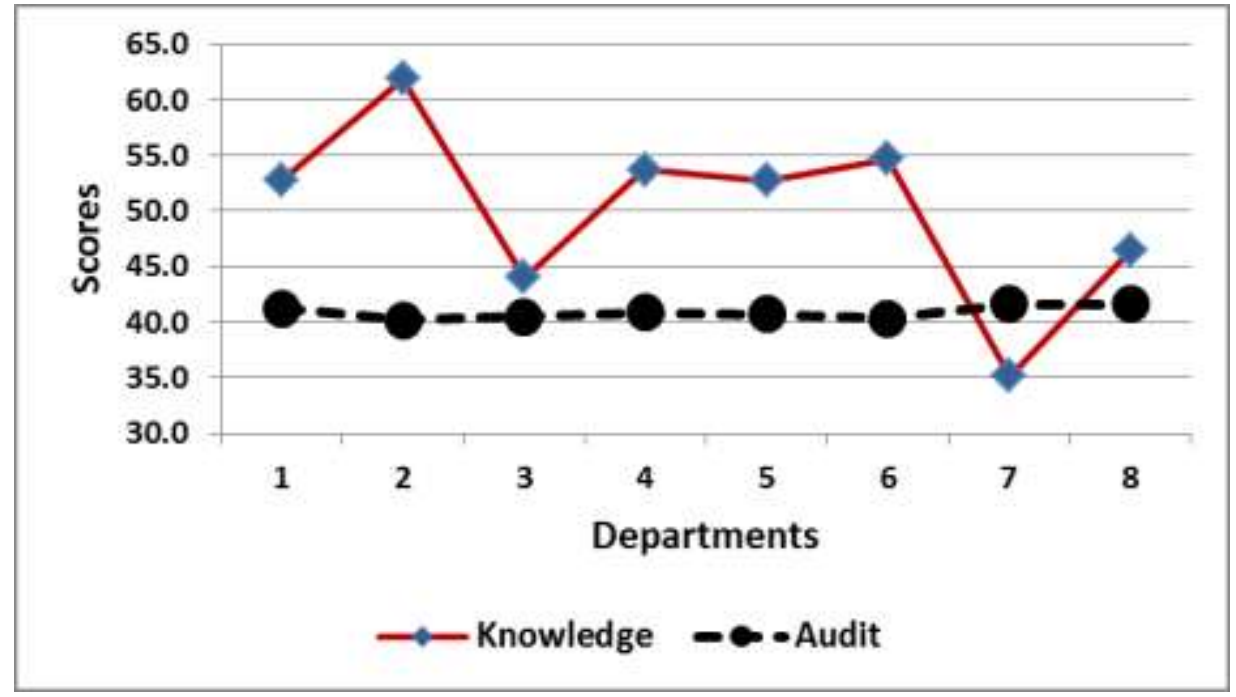

Figure (4): Ecologic correlation matrix of nurses' knowledge and audit scores

\section{DISCUSSION:}

In the era of evidence-based healthcare, nursing must demonstrate that care nurses provide is associated with optimal patient outcomes, and a high level of quality and safety. Nursing documentation is the means through which evidence related to nursing practice can be generated (Strudwick and Hardiker, 2016). It can provide an important indicator of the quality of care provided for hospitalized patients (Lindo et al, 2016). Hence, nursing documentation is crucial to high quality, effective and safe nursing care (Vabo et al, 2016). Its quality, accuracy and development require followup and evaluation, which can be through auditing (Mykkänen et al, 2016).

The aim of the present study was to assess nurses' knowledge and auditing their practices regarding nursing care documentation in Mansoura University Hospital. The study findings revealed deficient knowledge about documentation among these nurses, with low perception of the barriers hindering it. Their audited performance is even lower than their knowledge.

The study was carried out on a sample of nurses with a wide range of age and experience. This would represent the whole spectrum of nurses working in similar settings, so that the external validity of the study findings would be high and allow generalizations from its results.

All nurses in the present study having a diploma degree as their nursing 
qualification. However, the majority had a secondary nursing diploma, while the rest were having the higher level of technical institute diploma. This is a common finding given the relative numbers of nurses graduating from these schools to those graduating from the technical institutes and carrying their diploma degree. This could have an influence on their knowledge and practice of nursing documentation as shown by Hameed and Allo (2014) in their study in Iraq. However, no such difference could be revealed in the present study, probably due to the nearly similar curricula related to nursing documentation in both diploma programs.

The present study assessed nurses' knowledge about documentation. The results demonstrate a generally deficient knowledge, with less than two-fifth of the nurses having total satisfactory knowledge about documentation. This is a worrying finding given the importance of documentation in nursing practice and its essentiality in quality patient care.

The foregoing present study findings are in agreement with previous studies, which reported similarly low levels of nurses' knowledge about documentation. Thus, in a study in Uganda, Nakate et al (2014) in Uganda found that more than two-thirds of the nurses in the study sample were having unsatisfactory level of knowledge about documentation. On the same line, Yearous (2011) reported that from approximately one-third $(29.9 \%)$ to two-fifth $(41.4 \%)$ of the nurses in three different hospitals had satisfactory knowledge of nursing documentation. On the contrary, in a study in Nigeria by Taiye (2015) showed that all the nurses in the sample had sufficient knowledge of nursing documentation. This could be attributed to continuing staff development endeavors in this latter study.

As revealed by the results of the current study, the area of documentation principles was the lowest in nurses' knowledge about documentation. Thus, more than three-fifth of them had no satisfactory knowledge about this basic area of nursing documentation. In fact, if the nurses were not knowledgeable of the principles of documentation, they would never be able to practice it in a correct manner. The finding is in congruence with Hameed and Allo (2014) whose study in Iraq demonstrated that the lowest nurses' knowledge about documentation was related to the area of its basic principles and in how to document. Their figure $(38.5 \%)$ is close to that of the present study $(42.0 \%)$. 
Furthermore, approximately one-half of the nurses in the present study had no satisfactory knowledge about the importance of nursing documentation. This is another significant problem with untoward consequences on the practice of nursing documentation. Actually, the deficient knowledge about the importance of documentation would lead to a reluctant attitude, and subsequent negative practice. In contrast, the majority of the nurses in a study in Denmark had high knowledge of the importance of nursing documentation (Søndergaard et al., 2016).

The current study has also solicited nurses' opinions or attitudes towards the barriers that may hinder their performance of quality nursing documentation. The study results demonstrated a very low perception of such barriers, where only less than one-fifth of them had a high agreement upon total barriers. This could have two contradicting explanations. The first is the actual absence of such barriers. The second is the inability of these nurses to perceive barriers because of their lack of knowledge. This latter explanation is the most probable as the study findings demonstrated that a significantly higher percentage of the nurses having unsatisfactory knowledge were having a low agreement upon the related barriers.

Another main objective of the present study was to assess nurses' practices in nursing documentation through the auditing of their patient records. The findings were alarming, since only one of the audited records demonstrated adequate practice of the nursing documentation. This indicates an extremely low practice of this essential nursing task in the study setting. Since only one nurse had adequate practice of documentation, no statistical analyses could be done to assess the influence of any of the nurses' characteristics on their practices.

The findings of the present study concerning nurses' practices of documentation are far lower when compared to the results of other previous studies. Thus, Mohammed (2013), in a study of the quality of nursing documentation in intensive care units in Port Said, reported that $44.0 \%$ of the nurses had adequate documentation. Moreover, Taiye (2015) found that all respondent nurses in Nigeria practiced effective documentation. Although our findings indicate the presence of a serious problem jeopardizing the quality of patient care, the extreme deficiency of nurses' practices could be in part due to the strict audit system applied in reviewing the records. 
In examining the relations among nurses' scores of knowledge and audited practice, the ecologic correlation method was used. It revealed significant strong negative correlations between nurses' knowledge scores and audited practice. The findings mean that increased knowledge is associated with lower practice towards barriers.

\section{CONCLUSION:}

Based on study findings, it can be concluded that: the nurses in the medical and surgical units of Mansoura University Hospital have inadequate knowledge about documentation, especially regarding its principles, and a few of them had related training. Yet, only minorities of the nurses agree about the barriers hindering quality documentation, the agreement upon these barriers is inversely related to the level of knowledge. Meanwhile, nurses' practices of documentation are extremely low as revealed through auditing.

\section{RECOMMENDATIONS:}

Based on the results of the present study, the following recommendations were suggested:

- Staff development is urgently needed to improve nurses' knowledge and skills concerning nursing documentation. This is of particular importance for diploma nurses.

- Continuous supervision of nursing documentation through regular and periodic auditing is suggested, with constructive feedback, as well as disciplinary actions for defaulters and rewards for good achievers.

- The hospital administration should address the barriers to adequate nursing documentation identified by the nurses, and provide all needed resources.

- The nursing schools' curricula should give more emphasis to nursing documentation, with more focus on its importance and principles.

- Further research is proposed to assess the impact of on-the-job training and application of electronic health records on nurses' practices in documentation.

\section{REFERENCES:}

American Nurses Association, House of Delegates. (2005): Implications of fatigue on patient safety and nurse safety. (Available from the American Nurses Association 
8515 Georgia Avenue, Suite 400, Silver Spring, MD 20910). Retrieved on May 11 2016 at: http://www.nursingworld.org.

Chelagat D., Sum T., obel,M., Chebor A., Kiptoo R., Bundotich P. (2013): Documentation: Historical Perspectives, Purposes, Benefits and Challenges, Nurses International Journal of Humanities and Social Science Vol. 3 No. 16 [Special Issue August 2013].

Cheevakasemsook A., Chapman Y., Francis K., and Davies C. (2006): 'The study of nursing documentation complexities', International Journal of Nursing Practice; 12: 366-374. http://dx.doi.org/10.1111/j.1440-172X.2006.00596.x

College of Registered Nurses of British Columbia, (2013): Nursing Documentation: Vancouver: CRNBC. P6. Retrieved on Jan 222016 at www.crnbc.ca/Standards/Lists/ StandardResources/334 Documentation Prac Std.pdf.

Darmer M.R., Ankersen L., Nielsen B.G., Landberger G., Lippert E., and Egerod (2004): The effect of a VIPS implementation programme on nurses' knowledge and attitudes towards documentation. Scand J Caring Sci; 18(3): 325-32.

DeLaune C.S. ., and Ladner K.P (2011): Fundamentals of nursing: standards \& practices, chapter 13, documentation and informatics, 4th ed., New York: Delmar Cengage Learning, pp. 216, 223.

Gordon J., and Watts C. (2011): Applying skills and knowledge: Principles of Nursing Practice F. Nursing Standard; 25(33): 35-37.

Gugerty B., Maranda M.J., Beachley M., Navarro V.B., Newbold S., and Hawk W. (2007): 'Challenges and Opportunities in Documentation of the Nursing Care of Patients', Baltimore, Documentation Work Group, Maryland Nursing Workforce Commission, viewed 21 July 2013, from http://www.mbon. org/commission2/ documentation_challen ges.pdf

Hameed R.Y., and Allo R.R. (2014): Assessment of nurses' knowledge about nursing documentation. Journal of Kufa for Nursing Science; 4(1):1-9. 
Hall A.(2005): Defining nursing knowledge. Nursing Times, Article,15 Feb 2013 Vol 101.

Hoban V. (2003): How to handle a handover. Nursing Times; 99(9):54-55.

Jones M. (2012): The Concept of Knowledge Essay Retrieved at 13 Oct 2013, available at www.antiessays.com/.../The-Concept-Of-Knowledge-35.

Kluwer W. (2007): Documentation. Lippincott Manual of Nursing Practice series. Philadelphia: Lippincott and Wilkins.

Leach M.J. (2008): Planning a necessary step in clinical care. Journal of Clinical Nursing; 17(13): 1728-1734.

Lindo J., Stennett R., Stephenson-Wilson K., Barrett K.A., Msn D.B., AndersonJohnson P., Waugh-Brown V., and Wint Y. (2016): An Audit of Nursing Documentation at Three Public Hospitals in Jamaica. J Nurs Scholarsh. 2016 Jul 26. doi: 10.1111/jnu.12234.

Lucita M. (2007): Nursing: Practice and Public Health Administration, Current Concepts and trends. Chapter 5, role of administration in maintaining: records and reports. 2nd ed., New Delhi: Elsvier.

Medical Dictionary for the Health Professions and Nursing Farlex (2012): medicaldictionary. The free dictionary. Com/nursing+audit.

Mohammed F. (2013): Quality of nursing documentation in intensive care units in selected hospitals in Port Said, F.O.N Port Said University.

Moulster G., and Turnbull J. (2004): Learning Disability Nursing. Chapter 5, the purpose and practice of learning disability nursing. British: Blackwell science, p. 65.

Mykkänen M., Miettinen M., and Saranto K. (2016): Standardized Nursing Documentation Supports Evidence-Based Nursing Management. Stud Health Technol Inform.; 225:466-70. 
Nakate M.G., Dahl D., Drake K.B., and Petrucka P. (2014): Knowledge and attitudes of select Ugandan nurses towards documentation of patient care. African Journal of Nursing and Midwifery; 2(1):057-065.

Parker M., and Smith M. (2010): Nursing theories \& nursing practice, 3rd edition. Philadelphia: F.A. Davis Company, p.150.

Phillips D.L.(2010): Manual of I.V. the therapeutics evidence-based practice for infusion therapy, 5th edition, U.S.A.: F.A. Davis company, p.25.

Søndergaard S.F., Lorentzen V., Sørensen E.E., and Frederiksen K. (2016): The documentation practice of perioperative nurses. A literature review. J Clin Nurs. 2016 Jun 21. doi: 10.1111/jocn.13445

Strudwick G., and Hardiker N.R. (2016): Understanding the use of standardized nursing terminology and classification systems in published research: A case study using the International Classification for Nursing Practice (®).Int $\mathrm{J}$ Med Inform.;94:215-21. doi: 10.1016/j.ijmedinf.2016.06.012. Epub 2016 Jul 29.

Taiye B.H. (2015): Knowledge and practice of documentation among nurses in Ahmadu Bello University Teaching Hospital (Abuth) Zaria, Kaduna State. Journal of Nursing and Health Science; 4(6):1-6.

Vabo G., Slettebø A., and Fossum M. (2016): An Evaluation of an Action Research Nursing Documentation Project. J Clin Nurs. 2016 May 18. doi: 10.1111/jocn.13389.

White L. (2005): Foundations of Basic Nursing, unit 3, communication. 2nd edition, U.S.A.: Thomson Delmar Learning, p.150.

White L., Duncan G., and Baumle W. (2011): Foundation of basic nursing, chapter 9, nursing process, documentation, and informatics, 3rd edition, Delmar cengage learning, Australia, p173-190.

Yearous S.K.G. (2011): School nursing documentation: knowledge, attitude, and barriers to using standardized nursing languages and current practices." $\mathrm{PhD}$ (Doctor of Philosophy) thesis, University of Iowa. 


\section{تقييم معلومات الممرضين ومراجعة ممارساتهم بخصوص توثيق الرعاية التمريضية}

$$
\text { نورا أحمد حسن حسن عبدالله، أ.م. د/ مني مصطفى شاذلي، د/ رشا إبراهيم السيد علي }
$$

بكالوريوس تمريض-جامعة المنصورة، أستاذ مساعد إدارة التمريض -كلية التمريض-جامعة عين شمس،

$$
\text { مدرس إدارة التمريض- كلية التمريض- جامعة بورسعيد }
$$

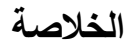

التوثيق التمريضي ضروري لجودة الرعاية الصحية. تهدف هذه الدراسة إلى تقييم معلومات الممرضين ومر اجعة ممارساتهم بخصوص توثيق الرعاية التمريضية في مستثفى المنصورة الجامعي في وحدات الباطنة

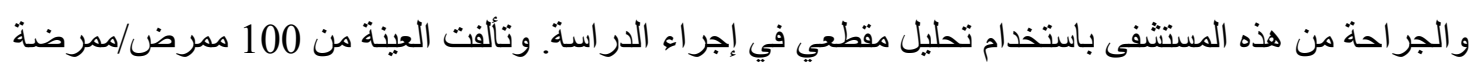
؛ بالإضافة إلى (557) سجل من سجلات المرضى. واستمر العمل الميداني من أبريل- حتى يوليو عام 2015.

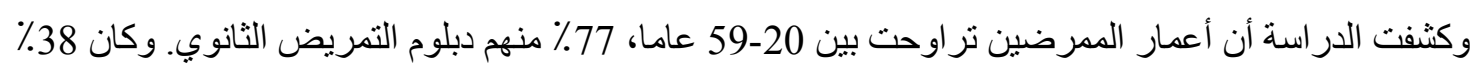
فقط من الممرضين لديهم معلومات مرضية عن التوثيق التمريضي. وكانت المخاوف القانونية تمثل أعلى عائق لدى الممرضين (45\%). كثفت مر اجعة السجلات نقص في أداء الممرضين بالنسبة للتوثيق التمريضي وخاصة فيما يتعلق بالبيانات الخاصة بتقييم المريض عند الدخول، والأدوية، ور عاية المريض و الاستجابة لهذه الرعاية. وقد استتنت الدراسة الحالية أن الممرضين لديهم معلومات قاصرة عن التوثيق التمريضي، و الأقلية منهم يتفقون على المعوقات التي تحول دون جودة التوثيق التمريضي. بعد مراجعة السجلات كان أداء الممرضين للتوثيق

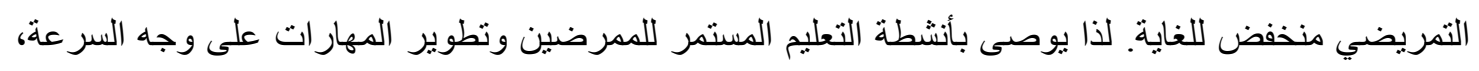
هناك حاجة إلى إثراف مستمر مع تغذية راجعة بناءة، مع المكافآت والإجراءات التأديية. 